\title{
Teaching music online: Changing pedagogical approach when moving to the online environment
}

\author{
Carol Johnson* \\ University of Melbourne
}

\begin{abstract}
The development of educational technology has provided platforms for undergraduate music courses to take place in an online environment. While technology is available, this does not mean that all teaching staff are ready for the pedagogical change required to implement teaching online. A transformation of pedagogical practice (that is, to online pedagogy) is required for teaching courses online. Researchers suggest that the use of social-constructivist learning and collaborative online learning models strongly support online student learning. The following case study explores how teaching staff in an American university music department $(\mathrm{N}=7)$ transformed their pedagogy when teaching undergraduate music courses online. The study highlights the diversity of perceptions about teaching music online, and the influence of these perceptions on the pedagogical approaches and strategies used when teaching and developing an online music course. The pedagogical elements of teaching music online were found to have connections with the community of inquiry framework's nexus of teaching presence, cognitive presence and social presence, and suggested a social-constructivist course design. Finally, the findings show that teaching staff experienced a shift of pedagogical approach when transitioning to teaching music online. Implications include assisting music faculty in the adoption of pedagogical approaches and that they should be addressed at individual, departmental and institutional levels.
\end{abstract}

Keywords: online music pedagogy; online teaching

\section{Introduction}

Undergraduate music majors have traditionally taken up their studies on a university campus. With the online environment demonstrating higher education learning outcomes equal to those of traditional learning environments (Tallent-Runnels et al., 2006), it is understandable that higher education music programmes explore the online learning context. Groulx and Hernly (2010) identified nine online master of music programmes, and this area has seen substantial growth since their study. An increased number of online master of music degrees are now represented by institutional members accredited by the National Association of Schools of Music (NASM) (http://nasm.arts-accredit.org/). A study of 343 American universities completed by Johnson (2017), identified that approximately 40 per cent of National Association of Schools of Music (NASM) institutions in 2015 offered online undergraduate music courses. Subset data from the study indicate online music course offerings have been increasing at an exponential rate since 2008 (Johnson, 2017). The current online learning landscape implies a shift from the traditional face-to-face teaching model in higher education music courses.

\footnotetext{
* Email: carol.johnson@unimelb.edu.au

CCopyright 2017 Johnson. This is an Open Access article distributed under the terms of the Creative Commons Attribution Licence, which permits unrestricted use, distribution and reproduction in any medium, provided the original author and source are credited.
} 
Given the adoption of online learning, this case study investigated an NASM university offering undergraduate online music courses. Research questions that guided this inquiry focused on the construction and development of effective online music course design and pedagogical approaches used by faculty members when teaching music online. The case study was bound within its unique institutional unit of analysis (Yin, 2014) and, while it is not generalizable (Lincoln and Guba, 1985), implications may be transferable to faculties or programmes interested in teaching music online. Findings suggest that there is a pedagogical shift that happens to faculty members when they transition from a traditional face-to-face model of music teaching to the fully online environment.

The purpose of this paper is three-fold: to highlight the need for a social-constructivist pedagogical mindset for online course design, to discuss case findings regarding the opportunities and challenges of various types of pedagogical mindsets used in online music courses, and to highlight professional development implications for universities offering undergraduate online music courses.

\section{Theoretical framework}

This case study is set within a social-constructivist theoretical framework. Supported by the inherent necessity for a scaffolded learning model when teaching music (Scott, 2006) and the participatory art of musicking (Small, 1998), this theoretical framework addresses both the inner and outer worlds of the musician. Built upon the constructivism writings of Piaget (1970) and Dewey (1910), Vygotsky (1978) posited that inherent dialogical and interactive aspects of learning (that is, social constructivism) were integral aspects of constructivist learning. Together, these interconnected theories support an individual's experience in learning through action and how individuals construct their knowledge, interact with knowledge and make meaning from experience (Bandura, I98I; Jonassen, 20 I3; Vygotsky, 1978).

\section{Setting the background}

Baccalaureate music programmes have traditionally included the cultural and collaborative contexts of music (Campbell and Hebert, 20I0; Green, 20I4), been comprised of a pattern of general music courses (for example, music history and music theory) and maintained a limited use of technology (Rees, 2002). As such, undergraduate music programmes are designed for music majors (that is, a four-year baccalaureate programme in music) and programme structures could be enhanced with the aid of online learning to include courses by international guest artists, to deal with niche topic areas, and to provide alternative options for campuses with limited capacity.

Online technology can help meet the community needs of musicians (Green, 20 I4; Salavuo, 2006), provide collaborative discussion opportunities for musicians (Biasutti, 20I5), and promote deeper music learning and cognitive development (Coffman, 2002; Dye, 2007). Research further confirms the effectiveness of learning music through online technology (Draper, 2008; Dye, 2007; Eakes, 2009; Hammond and Davis, 2005). However, established pedagogical methods to design artistically based courses effectively are not yet abundant (Adileh, 20I2). For this reason, increased use of technology aligned to practical pedagogy is warranted (Bowman, 20I4; Ruthmann and Hebert, 20I2). 


\section{Social constructivism and learning online}

Harasim (2017) suggests educators may not be adopting technologies in their teaching, even though technology is ubiquitous. Various factors can lead to the lack of technology adoption, including the overarching focus on developing technology skills in professional development, rather than on developing the pedagogical knowledge for incorporating technology in teaching (Macdonald and Poniatowska, 20I I).

Pedagogical knowledge adoption combined with technology (for example, Mishra and Koehler's (2006) technological, pedagogical and content knowledge (TPACK) model) can assist faculty in determining their pedagogical choices in conjunction with discipline content and technology for the betterment of student learning outcomes. A well-designed online learning environment can provide students with 24/7 access to materials for multiple viewing of resources (O'Callaghan et al., 2017); regulation of learning, flexibility of learning schedules, and accessibility accommodations (Henderson et al., 20I7); inclusion of learning materials in text, video, audio and graphic presentations (Meyer et al., 2014); and the availability for developing a collaborative learning environment (Harasim, 2017).

Use of a collaborative learning design in the online environment supports student learning (Ito et al., 20I3). Lock and Johnson (2015) identify online collaborative learning environments that provide three types of interactive learning exchanges: student-to-student, student-to-content and student-to-instructor. Together, these three types of interactions provide students with a triangulation of learning through a framework based in social-constructivist learning theory.

The field of music education can be positively affected by how students learn when using new technologies (Purves, 2012; Webster, 2007). Scott (2006) suggests that a 'deep approach to constructivist theory requires that learning provides students opportunities to link new learning to previous understandings and to interpret this new knowledge through experience' (17). Learning is also social in nature, as supported by Akyol and Garrison (2008). They suggest that one's pedagogical choices within the online environment should address three key areas: teaching presence, cognitive presence and social presence. These three presences are denoted as concentric circles that form the community of inquiry framework. Online learning, they suggest, 'should be designed, facilitated and directed based on the purpose, participants and technological context of the learning experience' (Akyol and Garrison, 2008: 18). Therefore, it is posited that if we can connect the learner by way of constructivist and social-constructivist experiences to ignite the creative thinking process of learning, then deep learning can be achieved.

With the important connections of technology to online learning, it becomes relevant to consider how inclusion of technology affects student learning in general. Focusing on the inclusion of educational technology in learning, Jonassen (2013) addresses how digital technologies could aid students' learning. He suggests that experiential, first-hand learning through action can build upon their active mental, physical and emotional constructs by seeking resolution or solution through a project or problem inquiry.

Attuned to 'authenticity' (Jonassen et al., 1995: 21), the progress of educational technology highlights the shift from the objectivist notion of teaching to one of building learning through increased interaction with online technology. According to Jonassen et al., teacher involvement in learning was reduced from over 80 per cent to between 10 and 15 per cent when online technology use was observed. Such an extreme paradigm shift set the stage for pedagogical studies in technology and online learning, as noted by Laurillard (2012).

Online learning is not a panacea for poor pedagogy (Bowen et al., 20l3). While some learning management systems (LMS) permit both asynchronous and synchronous learning opportunities, which tools are implemented and how these tools are implemented can be designed in a myriad ways. In addition, teaching staff may or may not be part of the online course-design process. 
Therefore, one must not only consider the technological developments of online learning, but also effective pedagogical approaches and how student interaction (that is, social constructivism), motivation and perceptions are deeply connected with learning music online (Adileh, 2012; Garrison, 20I I; Herrington et al., 20I4; Waldron, 20I3).

\section{Online music pedagogy}

The body of literature examined centres on a small amount of available research about learning music online. The limited quantity of research itself suggests a need for an extended body of studies exploring online music learning. This section takes a closer look at the development of an online music pedagogy - the pedagogical aspects influencing course development and learning outcomes in online music courses.

An overall pedagogy for teaching music online has not yet been established (Adileh, 2012; Bowman, 2014). However, as noted above, social constructivism is an integral pedagogical component for a supportive online learning experience. To bridge general online learning pedagogy and music pedagogy, Johnson (2016) suggests a framework for teaching music online. Her study suggests design, communication and assessment are three central components to teaching music in the online environment. These elements were found to be integral to designing and implementing online music courses successfully to support student learning. This researchinformed study provides an initial exploration of the development of an online music pedagogy.

Positive learning outcomes for music students using the online and ICT environments include flexibility of location and decrease of equipment changes (Biasutti, 20I5), increased creative opportunities for musical learning in studio production (King, 2016), overall musicmaking through the inclusion of technology (King and Himondes, 2016), ease of dialogical exchanges for collaboration, and effective content and knowledge learning (Adileh, 20 I2; Draper, 2008; Dye, 2007). Internet bandwidth means that there are still notable latency challenges when using synchronous video- and audio-conferencing software (Brändström et al., 20I2). However, adaptation of one's teaching approach or the use of additional resources (such as accompaniment tracks) decrease such challenges.

As observed in many music departments in the United States and Canada, performancebased teaching staff are generally performance-based graduates. While their terminating degrees in performance demonstrate expertise in performance, this suggests that many music faculty members may not have background expertise in teaching. In a study by Fredrickson (2007), later replicated by Fredrickson and Brittin (2009), students in performance-based degrees were surveyed using Mills's (2004) student survey on attitudes towards teaching music after obtaining a university degree. Music students in both studies identified that they would need more training in music instruction if they taught in the future. In 2013, Frederickson et al.'s study of $5 \mathrm{I}$ fulltime music faculty administered Mills's (2004) questionnaire, but adapted for use with faculty. Fredrickson et al. found that 83 per cent of faculty identified that their 'best students' (2013: 338) would likely become music teachers at higher education level. These studies suggest that performance-based degree students go on to become music teachers, and that development of instructional strategies may be lacking for current and future undergraduate music faculty.

Given the various synchronous and asynchronous tasks available in the online environment (Palloff and Pratt, 20II), the wide range of course design strategies employed in online teaching (Garrison, 20II) and challenges for student motivation in online learning (Picciano, 2002), teaching music online requires attention to its pedagogical approach (Bowman, 20I4). Pedagogical choices in the online environment regarding approaches to course design, degrees of teacher and student interactivity, and forms of student learning activities are not identical to the 
traditional music classroom. Incorporating online pedagogy into online music courses suggests an increased attention to social-constructivist teaching methods. However, there are currently gaps of research-based evidence regarding teaching methods in higher education online music courses (Bowman, 20I4; Ruthmann and Hebert, 20I2). Therefore, this study sought to explore evidence to demonstrate pedagogical mindsets used in online music teaching so as to identify beneficial learning approaches specific to the online music course. The research question guiding this inquiry was: what pedagogical approaches are used by teaching staff when teaching music online?

\section{Method}

The case university, herein given the pseudonym 'Mid-Western', was a small university campus located in the mid-western United States. Its total student population was less than I,500 students. Seven members of staff took part in the study. Data were collected through 30-minute semistructured interviews $(n=6)$ and a 60 -minute focus group discussion $(n=6)$. After the recorded interviews and discussions were transcribed, they were inductively analysed and themed using first and second coding (Saldaña, 20I3).

\section{Case overview}

Mid-Western was described by online music teaching staff as offering rigorous academic distance courses. Professional development support was given to both students and faculty members during its early technology initiatives in the late 1990s. Teaching staff joining the music department had the option to attend various workshops given by Mid-Western staff about learning to teach in the online environment.

Mid-Western's music programme was accredited by NASM, and had students taking the programme either on location or online. Online students were able to complete a bachelor of music degree by completing standard NASM four-year music course requirements through a hybrid (blended) or a fully online course format (with the exception of applied lessons). Applied lessons were not part of the online format. (Online students took their applied lessons with a university-approved instructor at their home location.)

Mid-Western had a history of teaching undergraduate music courses in the online environment. The first online music course, 'Music fundamentals', was made available to music students in 2004. Additional music courses were added until a suite of online courses formed a complete four-year bachelor of music degree. Online music courses in the degree programme included: 'Aural skills', 'Music history', 'Conducting', 'Music theory', 'Pedagogy', 'Piano proficiency', 'Music appreciation' and 'Music fundamentals'. Applied lessons were taught on location by department-approved instructors, with examination assessments conducted by university faculty. By September 20I4, eight faculty members were teaching 52 students in the online environment.

\section{Participants}

Seven faculty members participated in the case study $(\mathrm{N}=7)$. Teaching staff participated in semistructured interviews and in a focus group discussion. Examples of questions asked during the interviews and discussion included: 'What do you consider are effective concepts for designing and teaching online music courses?' and 'Can you explain how you may have modelled this in your teaching and online course designing experience?' 
Teaching staff had a variety of music performance and teaching backgrounds. Six of the seven participants were new to teaching in the online environment upon their arrival at MidWestern.

Five of the six participants interviewed, and four of the six teaching staff in the focus group, had taught an online music course prior to autumn 20I4. One participant had prior experience as an online student. In general, participants learned how to teach online as they were assigned their teaching loads (that is, 'trial by fire') and described their online teaching abilities as skills and knowledge that developed over time during their teaching. Table I outlines the online teaching experience of teaching staff participants.

Table I: Characteristics of teaching staff participants

\begin{tabular}{lcc}
\hline Years of online teaching & Faculty interviews & Faculty focus group \\
\hline 0 years & $\mathrm{I}$ & 2 \\
I-2 years & $\mathrm{I}$ & $\mathrm{I}$ \\
$\mathbf{3}-\mathbf{5}$ years & $\mathrm{I}$ & $\mathrm{I}$ \\
$\mathbf{6}-10$ years & 2 & 2 \\
10 or more years & $\mathrm{I}$ & 0 \\
Total & 6 & 6 \\
\hline
\end{tabular}

Participants had diverse backgrounds of online teaching experience and differing opinions about the extent to which music should be taught in the online environment. For example, the two participants with only one year of online teaching experience held opposite views about the teaching of music online. One felt that music could be learned in the online environment with effective course design, while the other felt that the online environment was not optimum for learning music. There were similar differences of opinion among participants who had between two and five years of online music teaching experience. Those with five or more years of experience of teaching music online agreed that music could be taught in the online environment when interactive (that is, social constructivist) course design was incorporated.

Teaching staff at Mid-Western created their own online course in Blackboard, an online learning management system with synchronous and asynchronous activity options. Course structure, content style and types of learning activities varied by instructor. Some instructors used similar learning tasks to their traditional courses (for example, research papers), while others gave students opportunities to demonstrate their knowledge through video presentations, collaborative online tasks, discussion forum groups and e-portfolio development. The complexity of technology used for online student learning tasks generally aligned with the technology proficiency of the instructor.

\section{Methodology}

This study used case study to investigate the phenomenon of pedagogical approaches to teaching music in the online environment. Case study research has been utilized in social sciences research since the early twentieth century (Yin, 2014). Not to be confused with the objectification of an individual case or record, case study itself is a methodological path (Creswell, 20I2; Yin, 20I4). It is used to illuminate a unique and bounded unit (Miles et al., 20I4; Yin, 20I4) contained by both its physical context (for example, a specific school environment), and time (for example, 
a six-week study). The outcomes of case study research provide insight into a phenomenon (for example, teaching music online) through in-depth descriptions of specific, complex social exchanges and events.

Within this case study design, the single, bounded unit is the chosen individual institution that provided online music courses for students on the bachelor of music programme. The unique qualities of the case are further defined by the type(s) of online music courses offered in the bachelor of music programme, the length of school semesters, and the institution's student and faculty population participating in the study.

\section{Method}

Six of the seven teaching staff participated in interviews and six participated in a focus group. Interview and focus group data were analysed using in vivo coding and first and second cycle descriptive coding (Miles et al., 20I4). In vivo coding was used 'to ground the analysis from [the participants'] perspectives' (Saldaña, 2013: 6I). In vivo coding further 'permits the demonstration and evidencing of participants' perspectives that directly contribute to the phenomenon' (Saldaña, 2013: 94). In addition to in vivo coding, emotional coding, process coding (that is, the use of gerunds and actions), and descriptive coding (that is, attribute coding) were also included to provide a well-rounded analysis of the phenomenon.

\section{Findings}

The findings identified themes specific to teaching philosophies and pedagogies, perceptions of online learning, and institutional supports that influenced how to teach online. These three significant markers were found to impact and influence each other. While faculty members held various beliefs on the use of individual and collaborative activities in their teaching, their perceptions of online learning influenced those beliefs. With time and experience with online teaching, faculty members grew in their abilities to teach online, which further influenced their practical experience on how to teach music in the online environment.

\section{Teaching philosophies and pedagogies}

Beliefs, perceptions and value statements were stated or implied during the interviews and faculty focus group discussion. As faculty described how they designed a course, they often incorporated value statements about why they used certain teaching methods, their personal perceptions of specific teaching methods, and how the online teaching environment enabled learning opportunities or presented challenges. For example, Anna described her course design as 'authentic ... it has something to do with real music'. Online music courses designed and developed by faculty members were moored foundationally not only in pedagogy but also in teaching philosophy, perceptions and beliefs about the learning of music in an online environment. Consequently, engaging learning tasks and overall course design were realized, or not, from faculty members' teaching philosophies. For example, Anna believed that collaboration was important for learning, and from that belief she purposely designed activities that required students to collaborate. One example of collaboration was the use of VoiceThread, which allowed students to comment together, via text, audio or video, on specific instructor-led questions.

The participants represented a wide spectrum of past teaching experiences, reactions to teaching online and perceptions of teaching online. Anna, 'grew with that entire programme ... 
the entire time', and was described as a leader in adopting new learning technologies and learning activities. Another participant, Thomas, described starting to teach music online as a 'trial by fire', and noted how he used the same individual learning activities from his traditional courses in his online courses. While aware that learning can take place through online collaboration, this faculty member was seemingly reluctant to incorporate additional technology and collaborative tasks specific to the online platform. However, newness to online teaching did not seem to be a factor for Albert. He identified clearly his willingness to look for ways to better facilitate student learning, and increased the aspect of community in his courses by seeking assistance from peers and online web-based sources.

Three overall perceptions surfaced in participant interviews regarding teaching music in an online environment: (I) online teaching was more challenging because of its set or published format; (2) both environments had 'a lot of crossover' (Thomas) regarding teaching set-up; and (3) the online environment was better able to enrich learning because of the visible nature of online work. While two participants suggested that the online environment permitted students to have a personalized learning experience, three participants slightly favoured the face-to-face learning environment.

Those favouring face-to-face learning described interactive exchanges and development of community as inherent challenges in the online environment. Specifically, Pat and Thomas noted that the face-to-face environment enabled better personal contact and ease of direct communication, which consequently allowed for the development of more advanced musical concepts. However, these instructors also agreed that the online environment could allow for student learning, but it was just 'more difficult' (Thomas) and 'took a long time' (Pat) to prepare for it.

The importance of music discipline expertise was identified through the examples and tasks that teaching staff presented to students. Specifically, teaching staff identified essential learning requirements that applied to both traditional music teaching pedagogy and online music teaching. For example, as instructors described their learning tasks, it was noted that while a learning task (such as listening to a musical work or reading a musical score) may have been a traditional teaching method, it was also a necessary and foundational element for learning music in any environment, including online. The transformation of a task from a traditional teaching method to an online format required certain levels of technological skills, such as the ability to use a web camera or create video feedback. However, it was also noted that when technology did not work properly (for example, when latency, or time shifting, occurred), teaching staff could use their music expertise to overcome the technological issue. For example, Pat described how her expert musicianship allowed for expert teaching when she stated:

So, if they play a chord, sometimes I can't hear what the chord is because all I hear is distortion ... I have perfect pitch, so it's helpful. I can just hear and look at their hands and know what keys they're playing.

The intricacies of expert discipline knowledge were part of a foundational premise for teaching and learning both theory- and performance-based practices of music at the post-secondary level.

Analyses of philosophical beliefs also highlighted that there was a need for a cultural musician context to be created online. This context was described in many ways by different participants. Anna spoke of the need for online music to be:

taught within that same cultural context, or that, really, that disciplinary context ... The idea of having live interaction ... I just think it's crucial at some point. I don't know how much is needed; I don't know how little one could get by with. But, for me, it needs to be an integral part of the learning. 
The act of experiencing music - performing, writing, reading, listening and producing - was described as preferable by six of the seven teaching staff. One-dimensional exchanges, as found in asynchronous learning (for example, discussion forum postings) were described by Anna as 'flat'. Specifically, she stated, 'that's musicians again speaking. So, there are a lot of people who think that flatness is just perfectly fine. I think for those of us who are not into that type of communication, it's really hard.' Together, these participants suggested that music courses presented in an online learning environment should address the inherent dynamic communication exchanges found in the performance and experiential foundations of music (that is, musicians performing with other musicians).

Faculty members' pedagogical influences also came from their self-guided learning experiences. George described his online teaching as being grounded in his previous traditional teaching. His use of organization of course content was one helpful approach borrowed from his traditional teaching pedagogy. Highlighting the pedagogical challenges of teaching online, Thomas commented that he was not sure how to teach online and said that he was, 'finding [his] own way' as he tried various approaches, seeking success. Albert described his approach to teaching music online based on his previous experiences as an online student.

Faculty members also made reference to specific pedagogy deemed helpful as they transitioned to, or created, their online teaching environments. Anna succinctly described online teaching through the lens of instructional design. She stated, 'teaching should occur in that central part of TPACK [technology, pedagogy, and content knowledge]' and 'the middle [of TPACK] is where we have to be working.' TPACK was a highly influential learning theory for this particular faculty member, whose background included previous formal learning in educational theories.

Various faculty members' explanations of pedagogical influences suggested that the successes and challenges of self-guided learning can influence the integration of learning theories without extensive training. As several of the faculty remarked, learning theories such as backward design (that is, planning a course starting with the end learning task in mind) were viewed as effective approaches to teaching, even if a faculty member was not familiar with the formal approach. As Edward succinctly stated, 'I was thinking about what type of learning models but I don't really think about it that way.' When Edward was asked to unpack this statement further, he identified that he did not know the names for specific learning models.

Together, the combination of faculty pedagogies and perceptions suggested that faculty seek to create a specific type of learning environment for their students. Their pedagogies suggested that they have foundational beliefs and values about a strong connection between communication and learning for the unique context of music learning.

\section{Perceptions of online learning}

The perceptions of teaching staff about what could be learned in the online environment influenced the learning approaches that they used. For example, when faculty described how they perceived teaching in the online environment, five faculty members described a process of incrementally adapting to teaching music online. Edward revealed, 'I was terrified when I first started teaching online courses, and every semester I learned a little bit and a little bit.' Challenged by new technologies, Albert also described the adoption of technology skills.

As faculty grew in their confidence in the online environment, they described online teaching by way of specific problems they encountered. That is, problem-solving skills were used to address challenges particular to an online environment (for example, students lacking motivation to participate in online discussions). As Albert adjusted to being more comfortable with teaching online, he explained that he needed to 'figure out a way that online people can share their 
paper live and can get criticism from each other live'. Having grown with the programme, Anna explained how she knew very little about technology when she started, yet was excited to learn how to incorporate technology into her teaching. These comments suggest that the faculty had an openness to teaching music in the online environment.

However, there was variation in what online learning activities were chosen. Two instructors, Anna and Edward, described the inclusion of online group learning or peer review activities, as well as the use of collaborative learning tasks and multiple interactive technology tools (for example, blogs, wikis and VoiceThread). Edward described a positive outcome with students who embraced peer interaction in the discussion area. He stated: 'They would have to comment on at least three to five other people's comments. ... And so, over time I see them building relationships.' Conversely, another faculty member, George, admitted, 'I haven't done that [peer review] but l've been toying with the idea of doing it.'

Teaching staff held different expectations about the online learning environment: pedagogical expectations, interaction expectations and basic participant expectations. Pedagogical expectations created both opportunities and challenges for how instructors and students interacted with their learning within the online environment. Thomas observed, 'I like to see them on a podium waving their arms and not writing research papers', and lamented that an asynchronous video recording lacked the emotional charge that one can experience conducting live, in front of peers. Given a desire for students to receive real-world experiences when learning, Thomas expressed some frustration with trying to fit a face-to-face course activity into his online environment. Additionally, instructors did not provide students with encouragement to take the role of facilitator in discussions or other learning tasks.

As a result of their perceptions of online learning, instructors were often challenged in how they transitioned from a traditional pedagogy to an online pedagogy. Pat highlighted a good example of this challenge. She recalled saying to a student, 'I would love to teach you but I can't because this medium, like, I can't hold your hand and tell you what to do. And there's also that delay [latency].' This faculty member demonstrated a perceived understanding (that is, music can only be taught through physical modelling) of what she thought possible in the online environment and made pedagogical decisions based on her traditional method of teaching (for example, kinesthetic modelling).

Other challenges faced by instructors included their perceptions about the limitations of specific skills that it is possible for students to learn within an online environment, and inhibitions about teaching via video recording - not using video in their teaching because they either did not know how to make a video, did not think a video would be helpful, or both. For example, Pat suggested that she could never create a video because she wanted her sound and technique to be 'perfect'. Acknowledging the spontaneous nature of traditional teaching, Pat commented, '[In a classroom] I might have said a lot of random words that shouldn't be in there, but, it didn't matter because nobody's recording it.'

Teaching staff also had expectations of students, and voiced these expectations throughout the interviews. They expected students in the online learning environment to have adequate computer technology and good-quality internet access, to use appropriate discussion etiquette, and to demonstrate self-motivation and self-regulation. Anna noted that 'they have to accept that [online learning] means a different experience'. Edward described his online teaching experience: 'It [my teaching] changes constantly depending on the course, and each semester I find new things that come up.' Anna suggested: 'I think there are a million ways to get it [student participation] going', and consequently provided her students with multiple types of learning technologies for participatory learning experiences. These technologies included the use of 
collaboration in Google Docs and VoiceThread, the inclusion of teaching videos and audios, and film-making by student groups for presentations.

\section{Scholarly significance of the work}

As indicated by the findings, several faculty members brought their previous teaching philosophies to their online courses and aimed to adjust traditional teaching strategies for online learning. The notion of authenticity was critical for teaching music online, as music is both an art form and aural communication that is learned through practical application. As outlined below, this study suggests that instructor background plays an important part in an individual's approach to online instruction. Further, pedagogical elements (that is, community of inquiry's teaching presence, cognitive presence and social presence) can be influential markers for social-constructivist course design in online music courses. Finally, there is indication that faculty can benefit from institutional support in terms of professional development to both prepare and facilitate teaching music in the online environment.

\section{Influence of instructional approaches}

Online music pedagogy is unique to each member of teaching staff, yet fits into the broad range of interpretation for fully online courses as defined in online learning literature (Bowen et al., 2013; Garrison, 20II; Means et al., 2010). With this in mind, the influence of instructional approaches was apparent as faculty spoke of their progress in moving from their traditional teaching methods to the online learning environment. These methods identified ties to teaching philosophies, online pedagogy, and openness towards online music learning and learning designs, as seen in their examples and in their willingness to try technology-integrated teaching ideas.

As instructors shift to the online environment, they bring their previous teaching philosophies and experiences with them. Within the music context, this generally means that an individual's music teaching philosophy is identified within the traditional cultural and collaborative constructs of the music experience (Campbell and Hebert, 2010; Green, 20I4; Rees, 2002) and traditional music pedagogy (Jones, 2005; Reimer, 2003). Faculty members use familiar teaching philosophies (that is, faculty generally use the teaching approach by which they were taught) to define the instructional approaches they undertake when designing their online music course.

Teaching philosophies and experiences informed faculty member's online pedagogy through their past pedagogical influences, perceptions and expectations regarding online teaching, and participation in institutional support and strategies. Self-guided learning was found to be highly utilized, and was influenced by the faculty member's perceptions, pedagogies, and teaching strategies and learning models (for example, TPACK), or lack thereof. One faculty member alluded to the integration of technological knowledge, content knowledge and pedagogical knowledge to form the nexus of TPACK. Koehler and Mishra suggest that this approach allows:

... teachers [to] go beyond thinking of themselves as being passive users of technological tools and [to] begin thinking of themselves as being designers of technology - i.e. they learn to use existing hardware and software in creative, novel, and situation specific ways to accomplish their teaching goals.

(Koehler and Mishra, 2005: 95)

Online pedagogy was found to be unique to an individual's teaching philosophy and contrived within faculty members' expectations of teaching online. It is understood that faculty members in the study acknowledged the difference between teaching online and the traditional face-toface format, and consequently set out to adapt their pedagogy for the online environment. In 
a qualitative study by Johnson and Lamothe (2017), faculty navigate through changes, or shifts, as they experience the successes and challenges of designing and teaching music in the online environment. Garrison (20I I) iterates this need for a pedagogical shift when teaching online. He states: 'The challenge is to understand the emerging education environment and how we create and sustain communities of inquiry that will facilitate the development of higher-order learning' (18). Further online music studies (Dye, 2007; Eakes, 2009; King et al., 2017) explore pedagogical challenges (for example, technology tools and approaches to course design) in transitioning from face-to-face to the online teaching environment, which affirm the need for online music pedagogy in online music courses.

The findings also suggest that there is a difference between instructors' openness to online learning, the teaching strategies implemented, and instructors' formal education (that is, music performance degree versus education degree). This uncovers possible differences in pedagogical approaches when teaching in a traditional instructional format (that is, face-to-face) and the necessary skill set for developing online community and a sense of belonging with students (Palloff and Pratt, 20I I).

Picciano (2002) suggests that community building among online students is necessary at the beginning of a course so that students feel an initial sense of belonging has been established. The three instructors that demonstrated openness to online learning and technologies had either had previous experience as an online student, or identified themselves as someone that focuses on the community aspect for learner engagement. These faculty also identified their teaching approach as one that utilized diverse and social-constructivist music tasks, which are being identified in research as integral when connecting music learning and technology (Biasutti, 2015; Johnson and Lamothe, 2017; Keast, 2009).

\section{Pedagogical elements}

The concepts of cognitive presence, social presence and teaching presence from the community of inquiry framework (Anderson et al., 200I) provide a strategic way to explore pedagogical elements that influence the instructional design and facilitation used in online music courses. Each of the presences were found in the data analysed from participants, and revealed varying degrees of influence on online music courses.

\section{Cognitive presence}

A shared learning experience was valued among these faculty members, and consequently became visible in their course design. Edward and Anna both used reflective-thinking studentlearning tasks. Tasks using discussion boards and group project interactions provided students with opportunities to reflect on their understanding of the content, and then to share that understanding through discourse with their fellow students. These tasks evidenced student need for critical thinking skills when completing reflective tasks.

Garrison (20II) described cognitive presence as a form of 'facilitating the analyses, construction and confirmation of meaning and understanding within a community of learners through sustained discourse and reflection' (42). Additionally, the inclusion of problem-solving skills promotes a higher level of critical thinking skills (Jonassen, 1999; Jonassen, 2013), and provides students with practical opportunities for investigation. Based on these findings, it can be understood that faculty members incorporated cognitive presence into their instructional design by encouraging peer comments and interactions specific to their learning content. 
However, the depth of critical thinking skills used was not made clear from study findings because of the specificity of the research questions.

\section{Social presence}

Picciano (2002) identifies social presence as a 'sense of belonging' (22) for the student, and that the student has a 'strong positive and statistically significant relationship' (33) as a member in the online course. Strategic forms of interaction in an online course are relevant for student motivation and to decrease isolation as a result of student distance (Picciano, 2002). The inclusion of constructivist (Jonassen, 1999) and social-constructivist learning (Vygotsky, 1978) further supports student learning through learner-content exploration and participatory, or experiential, learning. From the research cited, it can be suggested that the purposeful inclusion of tasks and tools (that is, the use of synchronous tools, such as video, and asynchronous tools, such as discussion forums) to develop a sense of individual belonging by the faculty members helped students with the means to establish social presence.

\section{Teaching presence}

Johnson and Altowairiki (2017) propose that teaching presence has four components: (I) preparation; (2) design; (3) implementation; and (4) assessment. Through these interconnected areas of teaching presence, it can be suggested that the level of instructor understanding of online teaching and learning skills and strategies plays a part in encouraging or discouraging the overall teaching presence in an online environment. All teaching staff designed their own online music courses in the Blackboard areas. As identified in instructor interviews by the use of specific terminology, or descriptive explanations of types of learning tasks used in the online area, some instructors' course designs incorporated the use of scaffolded learning (Vygotsky, 1978), and constructivist and social-constructivist learning (Dewey, 1910). Teaching staff addressed the need to limit the use of technology to focus on the music curriculum, and identified the inclusion of tasks that students could personalize to their own interests. These findings suggest that teaching staff identified the importance of structured and organized course design, so that students were provided with a structure that led to effective course completion.

Garrison (20II) suggests that teaching presence also involves all stakeholders taking part in the facilitation of discourse in the online course. This aspect of teaching presence did not appear to be mentioned by all of the instructors. This indicates a place for improvement for faculty and a need for faculty members to understand the importance of shared stakeholder responsibility in the online learning context.

Through these interconnected areas of the community of inquiry model, it can be suggested that the level of instructor understanding of online teaching and learning skills and strategies plays a part in encouraging or discouraging the successful transition to teaching in an online environment. Therefore, it can be posited that instructors with limited experience or background in teaching and learning strategies and community-building strategies may find the online learning environment challenging regarding communication, or have a distinct preference for the traditional classroom or music studio environment.

\section{Institutional supports}

Laurillard (2012) suggests that the inclusion of technologies in teaching should be supported at both institutional and faculty levels. This exposes the areas of curriculum design and institutional 
policies, as well as teacher beliefs and attitudes, in facilitating the adoption of technology, and online learning, for the modern classroom. The findings from this case study suggest that faculty teaching music in the online environment hold varying beliefs, attitudes and opinions on using the online environment for learning music at the bachelor course level. Given the varying backgrounds of current and future faculty involved in teaching music online, and the limited exposure of many faculty to experiencing online social-constructivist teaching, professional development opportunities that address both general pedagogy and pedagogy that is specific to teaching music online are warranted.

\section{Conclusion}

It is understood that the availability of an online learning platform for music faculty does not equate with a singular pedagogical understanding of how to design or teach music in the online environment. As this study evidences, faculty identified various ways of teaching music online. However, the common thread of creating opportunities for students to learn through interactive and social exchanges (that is, a social-constructivist approach) was found by faculty to be the most promising method of engaging students in their learning.

As music programmes move toward including contemporary learning environments (that is, learning management systems), the positioning of pedagogical paradigms and identification of online instructional strategies that seek to integrate social-constructivist activities (for example, collaborative learning tasks and development of community interaction) become necessary. With these approaches, a strong online teaching presence in music can develop that benefits all stakeholders. A shift in pedagogical approach may be required for those in the music faculty who are unfamiliar with developing social-constructivist task design. Consequently, openness towards more online collaborative learning tasks in traditionally apprenticeship-dominated pedagogical approaches may require additional institutional supports that focus on developing and sustaining an innovative pedagogical mindset. Further research on the benefit of faculty mentorship programmes for online teaching staff, and overall staff development, is warranted if an online pedagogy is to be used effectively to enhance learning.

\section{Notes on the contributor}

Carol Johnson $(\mathrm{PhD})$ is a Senior Lecturer in Music (Online Learning and Educational Technology) at the University of Melbourne. Her research focuses on online music pedagogy, teaching and learning online, and the development of teaching capacity for online faculty. Carol mentors online music faculty using research-informed practices and apprenticeship. She has taught music in the online environment since 2004 and was a founding director of the Virtual School of Music.

\section{References}

Adileh, M. (2012) 'Teaching music as a university elective course through e-learning'. Australian Journal of Music Education, I, 7I-9.

Akyol, Z. and Garrison, D.R. (2008) 'The development of a community of inquiry over time in an online course: Understanding the progression and integration of social, cognitive and teaching presence'. Journal of Asynchronous Learning Networks, 12 (3-4), 3-22.

Anderson, T., Rourke, L., Garrison, D.R. and Archer, W. (200I) 'Assessing teaching presence in a computer conferencing context'. Journal of Asynchronous Learning Networks, 5 (2), I-I7. 
Bandura, A. (198I) 'Self-referent thought: A developmental analysis of self-efficacy'. In Flavell, J.H. and Ross, L. (eds) Social Cognitive Development: Frontiers and possible futures. Cambridge: Cambridge University Press, 200-39.

Biasutti, M. (2015) 'Assessing a collaborative online environment for music composition'. Journal of Educational Technology and Society, 18 (3), 49-63.

Bowen, W.G., Chingos, M.M., Lack, K.A. and Nygren, T.I. (2013) 'Online learning in higher education: Randomized trial compares hybrid learning to traditional course'. Education Next, 13 (2), 58-64.

Bowman, J. (2014) Online Learning in Music: Foundations, frameworks, and practices. New York: Oxford University Press.

Brändström, S., Wiklund, C. and Lundström, E. (2012) 'Developing distance music education in Arctic Scandinavia: Electric guitar teaching and master classes'. Music Education Research, 14 (4), 448-56.

Campbell, P.S. and Hebert, D.G. (2010) 'World beat'. In Anderson, W.M. and Campbell, P.S. (eds) Multicultural Perspectives in Music Education (Vol. 2). 3rd ed. Lanham, MD: Rowman and Littlefield, II5-25.

Coffman, D.D. (2002) 'Adult education'. In Colwell, R. and Richardson, C. (eds) The New Handbook of Research on Music Teaching and Learning. New York: Oxford University Press, 199-209.

Creswell, J.W. (2012) Educational Research: Planning, conducting, and evaluating quantitative and qualitative research. 4th ed. Boston: Pearson.

Dewey, J. (1910) How We Think. Boston: D.C. Heath and Co.

Draper, P. (2008) 'Music two-point-zero: Music, technology and digital independence'. Journal of Music, Technology and Education, I (2-3), I37-52.

Dye, K.G. (2007) 'Applied Music in an Online Environment Using Desktop Videoconferencing'. EdD thesis, Teachers College, Columbia University.

Eakes, K.W. (2009) 'A Comparison of a Sociocultural and Chronological Approach to Music Appreciation in Face-to-Face and Online Instructional Formats'. PhD thesis, Auburn University.

Fredrickson, W.E. (2007) 'Music majors' attitudes toward private lesson teaching after graduation: A replication and extension'. Journal of Research in Music Education, 55 (4), 326-43.

Fredrickson, W.E. and Brittin, R.V. (2009) 'Undergraduate music performance majors' attitudes toward private lesson teaching after graduation: A replication'. Southern Music Education Journal, 4 (I), I4-29.

Fredrickson, W.E., Moore, C. and Gavin, R. (2013) 'Attitudes of select music performance faculty toward students teaching private lessons after graduation: A USA pilot study'. International Journal of Music Education, 3I (3), 33I-45.

Garrison, D.R. (20II) E-Learning in the 2 Ist Century: A framework for research and practice. 2nd ed. New York: Routledge.

Green, L. (20I4) Hear, Listen, Play! How to free your students' aural, improvisation, and performance skills. New York: Oxford University Press.

Groulx, T.J. and Hernly, P. (2010) 'Online master's degrees in music education: The growing pains of a tool to reach a larger community'. Update: Applications of Research in Music Education, 28 (2), 60-70.

Hammond, J. and Davis, B. (2005) The Creative Use of Music Technology To Develop and Enhance Critical Listening Skills in Music. Hemsworth: Hemsworth Arts and Community College/iCi-Arts.

Harasim, L. (2017) Learning Theory and Online Technologies. 2nd ed. New York: Routledge.

Henderson, M., Selwyn, N. and Aston, R. (2017) 'What works and why? Student perceptions of "useful" digital technology in university teaching and learning'. Studies in Higher Education, 42 (8), I567-79.

Herrington, J., Reeves, T.C. and Oliver, R. (2014) 'Authentic learning environments'. In Spector, J.M., Merrill, M.D., Elen, J. and Bishop, M.J. (eds) Handbook of Research on Educational Communications and Technology. 4th ed. New York: Springer, 40I-I2.

Ito, M., Gutiérrez, K., Livingstone, S., Penuel, B., Rhodes, J., Salen, K., Schor, J., Sefton-Green, J. and Watkins, S.C. (2013) Connected Learning: An agenda for research and design. Irvine, CA: Digital Media and Learning Research Hub.

Johnson, C. (2016) ‘Developing a Teaching Framework for Online Music Courses'. PhD thesis, University of Calgary.

Johnson, C. (2017) 'Undergraduate online music course offerings rising exponentially: A research study'. Paper presented at the 10th International Conference for Research in Music Education, Bath Spa University, 24-27 April 2017. 
Johnson, C. and Altowairiki, N. (2017) 'Developing teaching presence in online learning through shared stakeholder responsibility'. In Vu, P., Fredrickson, S. and Moore, C. (eds) Handbook of Research on Innovative Pedagogies and Technologies for Online Learning in Higher Education. Hershey, PA: IGI Global, I5I-77.

Johnson, C. and Lamothe, V. (2017) 'Shared experiences in effective faculty support for learning to teach post-secondary music in the online environment'. Paper presented at the 10th International Conference for Research in Music Education, Bath Spa University, 24-27 April 2017.

Jonassen, D.H. (1999) ‘Designing constructivist learning environments'. In Reigeluth, C.M. (ed.) InstructionalDesign Theories and Models: A new paradigm of instructional theory (Vol. 2). Hillsdale, NJ: Lawrence Erlbaum Associates, 215-4I.

Jonassen, D.H. (2013) 'First principles of learning'. In Spector, J.M., Lockee, B.B., Smaldino, S.E. and Herring, M.C. (eds) Learning, Problem Solving, and Mindtools: Essays in honor of David H. Jonassen. New York: Routledge, 287-97.

Jonassen, D., Davidson, M., Collins, M., Campbell, J. and Haag, B.B. (1995) 'Constructivism and computermediated communication in distance education'. American Journal of Distance Education, 9 (2), 7-26.

Jones, P.M. (2005) 'Music education and the knowledge economy: Developing creativity, strengthening communities'. Arts Education Policy Review, 106 (4), 5-12.

Keast, D.A. (2009) 'A constructivist application for online learning in music'. Research and Issues in Music Education, 7 (I), Article 8, I-9.

King, A. (2016) 'Technology as a vehicle (tool and practice) for developing diverse creativities'. In Burnard, P. and Haddon, E. (eds) Activating Diverse Musical Creativities: Teaching and learning in higher music education. London: Bloomsbury Academic, 203-22.

King, A. and Himonides, E. (eds) (2016) Music, Technology, and Education: Critical perspectives. New York: Routledge.

King, A., Prior, H. and Waddington, C. (2017) 'The study of the effectiveness and impact of online learning for instrumental tuition in rural communities'. Paper presented at the 10th International Conference for Research in Music Education, Bath Spa University, 24-27 April 2017.

Koehler, M.J. and Mishra, P. (2005) 'What happens when teachers design educational technology? The development of technological pedagogical content knowledge'. Journal of Educational Computing Research, 32 (2), | $3 \mid-52$.

Laurillard, D. (2012) Teaching as a Design Science: Building pedagogical patterns for learning and technology. New York: Routledge.

Lincoln, Y.S. and Guba, E.G. (1985) Naturalistic Inquiry. Newbury Park, CA: SAGE Publications.

Lock, J. and Johnson, C. (2015) 'Triangulating assessment of online collaborative learning'. Quarterly Review of Distance Education, I6 (4), 6I-70.

Macdonald, J. and Poniatowska, B. (20II) 'Designing the professional development of staff for teaching online: An OU (UK) case study'. Distance Education, 32 (I), II 9-34.

Means, B., Toyama, Y., Murphy, R., Bakia, M. and Jones, K. (2010) Evaluation of Evidence-Based Practices in Online Learning: A meta-analysis and review of online learning studies. Washington, DC: US Department of Education. Online. https://www2.ed.gov/rschstat/eval/tech/evidence-based-practices/finalreport.pdf (accessed 29 July 2017).

Meyer, A., Rose, D.H. and Gordon, D. (2014) Universal Design for Learning: Theory and practice. Wakefield, MA: CAST.

Miles, M.B., Huberman, A.M. and Saldaña, J. (2014) Qualitative Data Analysis: A methods sourcebook. 3rd ed. Thousand Oaks, CA: SAGE Publications.

Mills, J. (2004) 'Conservatoire students as instrumental teachers'. Bulletin of the Council for Research in Music Education, $|6|-2, \mid 45-53$.

Mishra, P. and Koehler, M.J. (2006) 'Technological pedagogical content knowledge: A framework for teacher knowledge'. Teachers College Record, 108 (6), I017-54.

O'Callaghan, F.V., Neumann, D.L., Jones, L. and Creed, P.A. (2017) 'The use of lecture recordings in higher education: A review of institutional, student, and lecturer issues'. Education and Information Technologies, 22 (I), 399-4I5.

Palloff, R.M. and Pratt, K. (20II) The Excellent Online Instructor: Strategies for professional development. San Francisco: Jossey-Bass. 
Piaget, J. (1970) 'Piaget's theory'. In Mussen, P.H. (ed.) Carmichael's Manual of Child Psychology (Vol. I). 3rd ed. New York: Wiley, 703-32.

Picciano, A.G. (2002) 'Beyond student perceptions: Issues of interaction, presence, and performance in an online course'. Journal of Asynchronous Learning Networks, 6 (I), 2I-40.

Purves, R. (2012) 'Technology and the educator'. In McPherson, G.E. and Welch, G.F. (eds) The Oxford Handbook of Music Education (Vol. 2). New York: Oxford University Press, 457-75.

Rees, F.J. (2002) 'Distance learning and collaboration in music education'. In Colwell, R. and Richardson, C. (eds) The New Handbook of Research on Music Teaching and Learning. New York: Oxford University Press, 257-73.

Reimer, B. (2003) A Philosophy of Music Education: Advancing the vision. 3rd ed. Upper Saddle River, NJ: Prentice Hall.

Ruthmann, S.A. and Hebert, D.G. (2012) 'Music learning and new media in virtual and online environments'. In McPherson, G.E. and Welch, G.F. (eds) The Oxford Handbook of Music Education (Vol. 2). New York: Oxford University Press, 567-83.

Salavuo, M. (2006) 'Open and informal online communities as forums of collaborative musical activities and learning'. British Journal of Music Education, 23 (3), 253-7I.

Saldaña, J. (2013) The Coding Manual for Qualitative Researchers. 2nd ed. Los Angeles: SAGE Publications.

Scott, S. (2006) 'A constructivist view of music education: Perspectives for deep learning'. General Music Today, 19 (2), 17-2I.

Small, C. (1998) Musicking: The meanings of performing and listening. Hanover: University Press of New England.

Tallent-Runnels, M.K., Thomas, J.A., Lan, W.Y., Cooper, S., Ahern, T.C., Shaw, S.M. and Liu, X. (2006) 'Teaching courses online: A review of the research'. Review of Educational Research, 76 (I), 93-135.

Vygotsky, L.S. (1978) Mind in Society: The development of higher psychological processes. Cambridge, MA: Harvard University Press.

Waldron, J. (2013) 'User-generated content, YouTube and participatory culture on the Web: Music learning and teaching in two contrasting online communities'. Music Education Research, 15 (3), 257-74.

Webster, P.R. (2007) 'Computer-based technology and music teaching and learning: 2000-2005'. In Bresler, L. (ed.) International Handbook of Research in Arts Education. Dordrecht: Springer, I3 I I-28.

Yin, R.K. (2014) Case Study Research: Design and methods. 5th ed. Los Angeles: SAGE Publications.

\section{Related articles published in the London Review of Education}

The paper was published in a special feature of the journal called: 'Music education in context', edited by Hilary McQueen and Maria Varvarigou. The other articles in the feature are:

Black, P. (2017) 'On being and becoming a jazz musician: Perceptions of young Scottish musicians'. London Review of Education, 15 (3), 339-57.

Cooper, N. (2017) 'Design-based research as an informal learning model for choral conductors'. London Review of Education, 15 (3), 358-71.

Gande, A. and Kruse-Weber, S. (2017) 'Addressing new challenges for a community music project in the context of higher music education: A conceptual framework'. London Review of Education, 15 (3), $372-87$.

Hallam, S. (2017) 'The impact of making music on aural perception and language skills: A research synthesis'. London Review of Education, 15 (3), 388-406. 
Hart, A. (2017) 'Towards an effective freeware resource for music composition in the primary classroom'. London Review of Education, 15 (3), 407-24.

Holmes, S. and Hallam, S. (2017) 'The impact of participation in music on learning mathematics'. London Review of Education, 15 (3), 425-38.

Minors, H.J., Burnard, P., Wiffen, C., Shihabi, Z. and van der Walt, J.S. (2017) 'Mapping trends and framing issues in higher music education: Changing minds/changing practices'. London Review of Education, I5 (3), 457-73.

Rodgers, D. (2017) 'Community music as a vehicle for tackling mental health-related stigma'. London Review of Education, 15 (3), 474-87.

Sarazin, M. (2017) 'Can student interdependence be experienced negatively in collective music education programmes? A contextual approach'. London Review of Education, I5 (3), 488-504. 